\title{
Decisão de admissibilidade da denúncia no Superior Tribunal de Justiça: uma pesquisa quali-quantitativa
}

\author{
Decision on the admissibility of criminal complaints in the Brazilian \\ Superior Court of Justice: a quali-quantitative research
}

\section{João Henrique de Andrade ${ }^{1}$}

Universidade de Fortaleza - Fortaleza/CE, Brasil joaohenriquedeandrade@hotmail.com http://lattes.cnpq.br/2212701427166337

http://orcid.org/0000-0002-2744-5347

\section{Nestor Eduardo Araruna Santiago ${ }^{2}$}

\author{
Universidade de Fortaleza - Fortaleza/CE, Brasil \\ Universidade Federal do Ceará - Fortaleza/CE, Brasil \\ nestorsantiago@unifor.br \\ http://lattes.cnpq.br/4516474580462451 \\ https://orcid.org/0000-0002-2479-7937
}

\section{Uinie Caminha ${ }^{3}$}

\author{
Universidade de Fortaleza - Fortaleza/CE, Brasil \\ Universidade Federal do Ceará - Fortaleza/CE, Brasil \\ ucaminha@gmail.com \\ http://lattes.cnpq.br/7267460801914951 \\ https://orcid.org/0000-0002-3062-8427
}

1 Mestrando em Direito pela Universidade de Fortaleza. Membro do Laboratório de Ciências Criminais (LACRIM - UNIFOR). Advogado criminalista.

2 Doutor, Mestre e Especialista em Direito pela UFMG. Estágio Pós-doutoral pela Universidade do Minho. Professor Titular da Universidade de Fortaleza (Doutorado, Mestrado, Especializações e Graduação em Direito). Coordenador do Laboratório de Ciências Criminais (LACRIM - UNIFOR). Professor Adjunto da Universidade Federal do Ceará (Graduação em Direito). Advogado criminalista.

3 Pós-Doutora em Direito pela Universidade de São Paulo. Doutora em Direito Comercial pela USP. Professora Titular da Universidade de Fortaleza e Professora Adjunta da Universidade Federal do Ceará. Advogada. 
Resumo: Trata-se de análise de discurso do Superior Tribunal de Justiça (STJ) em relação ao juízo de admissibilidade da denúncia. Busca-se entender se a jurisprudência do STJ encontra eco no texto constitucional quanto à necessidade de fundamentação das decisões judiciais. Foram levantados 107 julgados no interstício de 2008 a 2019, em que se pretendeu compreender a evolução no entendimento jurisprudencial a respeito da necessidade de fundamentação da decisão de recebimento da denúncia após a edição da Lei n. 11.719/08. A metodologia utilizada é de caráter quantitativo e qualitativo. O estudo aponta que o STJ vem apresentando uma resposta inadequada ao texto constitucional, pois o juízo de admissibilidade como decisão judicial requer uma fundamentação à luz do art. 93, IX, da Constituição Federal e do art. 315 do Código de Processo Penal.

Palavras-chave: Processo penal; Decisão judicial; Fundamentação; Juízo de admissibilidade; Denúncia.

ABSTRACT: This is an analysis of the discourse of the Brazilian Superior Court of Justice (STJ) in relation to the judgment confirming the admissibility of the criminal prosecution. It seeks to understand whether the STJ's jurisprudence finds an echo in the constitutional text regarding the need to substantiate judicial decisions. 107 of them were raised in the interstice from 2008 to 2019, after the enactment of Law no. 11,719/2008. We intended to understand the evolution in the jurisprudential comprehension on the need to justify the decision whether to admit or not the criminal prosecution. The methodology used is both quantitative and qualitative. The study points out that the STJ has been presenting an inadequate response to the constitutional text, since the admissibility judgment as a judicial decision requires a justification in the light of article 93, IX, of the Brazilian Federal Constitution and of article 315 of the Criminal Procedure Code.

Kerwords: Criminal procedure; Judicial decision; Judgment of admissibility; Reasoning; Criminal prosecution.

\section{INTRODUÇÃO}

A presente pesquisa tem como objetivo analisar a jurisprudência do Superior Tribunal de Justiça (STJ) entre os anos de 2008 a 2019 quanto 
à necessidade de fundamentação da decisão judicial referente ao juízo de admissibilidade (recebimento da denúncia ou queixa), previsto no art. 399 do Código de Processo Penal (CPP), nos termos da minirreforma de 2008. Busca-se entender se a jurisprudência encontra eco no texto constitucional quanto à necessidade de fundamentação das decisões judiciais (art. 93, IX, Constituição Federal - CF).

Parte-se do pressuposto que a decisão que recebe a denúncia se trata de um ato judicial de caráter decisório, e por isso, necessitaria fundamentação. Diante disso, tem-se por objetivo observar de que forma o Superior Tribunal de Justiça (STJ), órgão judicial constitucionalmente encarregado da verificação de aplicabilidade uniforme da legislação federal, está se pronunciando sobre o assunto.

Para além de uma abordagem quantitativa, que procurou verificar o número de julgados entre os anos de 2008 e 2019, também procurou se apontar, do ponto de vista qualitativo, as razões de decidir nos acórdãos pesquisados no referido interregno, para, então, baseando-se no método hipotético-dedutivo, e também com lastro em análise documental e bibliográfica, verificar se a resposta dada pelo STJ está de acordo com o texto constitucional no que tange à necessidade de fundamentação.

$\mathrm{Na}$ atual sistemática do CPP, o juízo de admissibilidade da denúncia ocorre em dois momentos, conforme os art. 395 e art. 399 do CPP. No primeiro momento, o juízo, não rejeitando liminarmente, deve receber a denúncia, interrompendo o prazo prescricional previsto no art. 117, I do Código Penal (CP), para em seguida determinar que o acusado seja citado para responder por escrito à acusação. Após a resposta defensiva, o juízo realiza um novo juízo de admissibilidade da acusação, com base no conteúdo apresentado pela defesa, tendo como base o art. 397 do CPP.É justamente sobre o art. 399 do CPP que esta pesquisa se debruça, e que é objeto do primeiro item deste trabalho.

Em um segundo ponto, aborda-se o percurso metodológico realizado no presente estudo, começando pela coleta de dados realizada no sítio eletrônico do STJ para, em seguida, mostrar os resultados e discussão decorrentes do material coletado, sob o ponto de vista quantitativo. Após, faz-se a análise qualitativa dos julgados, com a finalidade de se verificar as razões de decidir no tocante à análise do art. 399 do CPP. 
Por fim, constata-se um paradoxo existente na jurisprudência do STJ em relação à necessidade de fundamentação do juízo de admissibilidade da acusação, o que não é compatível com o texto constitucional.

\section{Juízo dE ADMISSIBILIDADE DA ACUSAÇÃo E O PROCESSO PENAL EM TRÊS ETAPAS.}

Na redação original do CPP de 1941, o juízo de admissibilidade da denúncia ou da queixa era estabelecido nos termos do revogado art. 43, o qual determinava que a denúncia seria rejeitada quando os fatos narrados não constituíssem crime, quando já tivesse sido extinta a punibilidade ou quando não existissem condições para o exercício da ação processual penal. ${ }^{4} \mathrm{O}$ exame preliminar da acusação estava atado à discricionariedade do magistrado, pois se tinha como praxe o recebimento automático da acusação ${ }^{5}$. Vale lembrar que, nesta época, o interrogatório sucedia à citação válida do acusado, que somente depois apresentava defesa prévia, muitas vezes limitada à mera apresentação de rol testemunhal, já que nova oportunidade de serem analisadas as questões processuais ligadas à validade da relação processual penal somente aconteciam no momento da sentença. ${ }^{6}$

Da promulgação do CPP até o final do século XX, tentou-se adequá-lo aos textos constitucionais, como também às diretrizes internacionais apresentadas ao mundo no pós-guerra. Todavia, estes movimentos reformistas esbarravam - e ainda esbarram - em uma resistência ideológica autoritária, de forma a não admitir a mudança do papel do juiz no processo penal ${ }^{7}$.

4 A redação deste artigo, com pouquíssimas modificações, encontra-se no art. 395 do CPP, em razão das mudanças trazidas pela Lei n. 11.719/2008.

5 ZILLI, Marcos. O povo contra... As condições da ação penal condenatória. Velhos problemas. Novas ideias. Cadernos Jurídicos, São Paulo, a. 17, n. 44, p.147-162. Jul-Set/2016, p. 149

6 Neste sentido, cf. GOMES FILHO, Antônio Magalhães. A motivação das decisões penais. 2. ed. São Paulo: Revista dos Tribunais, 2013, p. 206.

7 PRADO, Geraldo. Crônica da reforma do Código de Processo Penal Brasileiro que se inscreve na Disputa da Policia pelo Sentido e Fundação da justiça criminal. In: COUTINHO, Jacinto Miranda. CARVALHO, L. G. Grandinetti 
No final dos anos 1990, formou-se uma comissão de reforma do CPP para que, em 90 dias, ela estivesse apta a rever os anteprojetos apresentados anteriormente pela Comissão de Reforma de $1992^{8}$ e exibir propostas viáveis à discussão. Esta nova comissão foi presidida pela Prof. Dra. Ada Pellegrini Grinover ${ }^{9}$ e teve como objetivo apresentar reformas pontuais: "a reforma total teria a seu favor a completa harmonia do novo sistema. Mas seria inexequível operacionalmente”, principalmente em razão da "morosidade própria da tramitação legislava dos códigos, a dificuldade prática do Congresso Nacional [...]"10. Foram apresentados 11 anteprojetos, dentre os quais se destaca, neste artigo, o relativo às modificações no procedimento comum ordinário e sumário, com o intento de equilibrar garantia e eficiência, deixando-o mais ágil e funcional, de modo a melhor preservar os direitos do acusado, mas sem perder de vista sua finalidade ${ }^{11}$.

Em um primeiro momento, apenas os anteprojetos sobre prisão especial e o interrogatório do acusado tornaram-se leis ${ }^{12}$. A partir de 2005, a tramitação dos Projetos de Lei oriundos desta comissão ganhou fôlego em decorrência da realização do "Pacto de Estado em Favor de um Judiciário mais Rápido e Republicano”, realizado em dezembro de 2004.

Castanho de. (Org.). O novo Processo Penal à Luz da Constituição. Rio de Janeiro. Lumen Juris. 2011, p. 8-9.

8 Em 1992 foi designado ao Ministro da Justiça Celio Borja a criação de uma comissão que apresentasse alternativas à legislação vigente (CPP e CPC). A comissão responsável pela reforma do CPP foi presidida pelo Min. do STJ Luiz Vicente Cernicchiaro e secretariada por Sidnei Agostinho Beneti. A comissão pretendi realizar reformas pontuais. No âmbito do procedimento ordinário havia uma proposta que buscava o aprimoramento através de um contraditório prévio do recebimento da denúncia, com base nos princípios da oralidade.

9 Comissão Grinover teve como demais integrantes: Petrônio Calmon Filho (Relator) Antônio Magalhães Gomes Filho, Antônio Scarance Fernandes, Luiz Flavio Gomes, Miguel Reale Júnior, Nilzardo Carneiro Leão e Renê Ariel Dotti (Portaria n. 61 de 20 de janeiro de 2000 - Ministério da Justiça).

10 GRINOVER, Ada Pellegrini. A reforma do código de processo penal. Revista Brasileira de Ciências Criminais, São Paulo. v. 31, jul-set. 2000, p. 66.

11 GRINOVER, Ada Pellegrini. A reforma do código de processo penal. Revista Brasileira de Ciências Criminais, São Paulo. v. 31, jul-set. 2000, p. 66.

12 A prisão especial foi instrumentalizada na Lei n. 10.258/01. Em relação ao interrogatório publicou-se a Lei n. 10.792/03. 
O então Ministro da Justiça, Marcio Thomaz Bastos ${ }^{13}$, defendeu a ideia de que se buscassem Projetos de Leis que já tivessem sidos debatidos e que pudessem apresentar uma modificação real na estrutura criminal. Assim, deu-se prosseguimento aos seguintes Projetos de Leis: n. 4207/01 (procedimentos); n. 4203/01 (Tribunal do júri); n. 4205/01 (provas); e, por fim, n. 4208/01 (medidas cautelares).

Os três primeiros foram aprovados e transformados, em 2008, nas Leis n. 11.689, n. 11.690 e n. 11.719, fazendo com que o CPP passasse por uma minirreforma ${ }^{14}$, não estruturante, com a qual buscou equilibrar a função persecutória estatal ao processo igualitário e democrático previsto na $\mathrm{CF}^{15}$. A Lei n. 11.719 reformulou o procedimento comum, em especial o ordinário, que passou a servir como modelo para os demais, previstos ou não no CPP, introduzindo o processo penal em três etapas: investigação preliminar, admissibilidade da denúncia e produção probatória ${ }^{16}$.

Pós-minirreforma, o CPP passou a determinar a realização do juízo de admissibilidade da acusação, extirpando assim o recebimento automático da denúncia. Conforme a exposição de motivos da Lei n. 11.719/08, e ao mesmo tempo seguindo o histórico das tentativas de reformas, buscou-se determinar o recebimento da denúncia em dois momentos: o primeiro em caráter liminar, com a análise da aplicação (ou não) do art. 395 do CPP; depois, após resposta à acusação, seria feita a análise pormenorizada dos requisitos da pretensão acusatória, com base no art. 397 do $\mathrm{CPP}^{17}$.

13 BASTOS, Marcio Thomaz. Reformar o processo penal. Folha de São Paulo. Disponivel em: < https://www1.folha.uol.com.br/fsp/brasil/fc2411200316. htm>. Acesso em 05 abr. 2020. .

14 SANTIAGO, Nestor Eduardo Araruna. Princípio da duração razoável do processo e direito processual penal: uma leitura estrutural da mini-reforma. In: SALES, Gabrielle Bezerra; JUCÁ, Roberta Laena Costa. (Org.). Constituição em Foco: 20 anos de um novo Brasil. 1 ed. Fortaleza: LCR, 2008, p. 237-246.

15 ZILLI, Marcos. O pomar e as pragas. Boletim do IBCCRIM, São Paulo, ano 16, n.188, jul. 2008, p. 02

16 PRADO, Geraldo. Prova penal e sistema de controles epistêmicos: A quebra da cadeia de custodia das provas obtidas por métodos ocultos. São Paulo: Marcial Pons, 2014, p. 45.

17 Exposição de motivo $\mathrm{n}^{\circ} 23$ do Ministério da Justiça. Publicada no diário da Câmara dos Deputados em 30 de março 2001. Disponível em: <http:// 
Durante a tramitação do Projeto de Lei n. 4.207/2001, que resultou na Lei n. 11.719/2008, acrescentou-se ao art. 396 do CPP o termo "recebê-la-á", fazendo que, com isso, surgisse uma dúvida a respeito do momento em que ocorreria o recebimento da denúncia. A modificação legislativa, finalmente aprovada, criou uma contradição entre o art. $396 \mathrm{e}$ o art. 399, tendo em vista que ambos preveem o recebimento da acusação, e desde já estabelecendo ser ilógica a existência de dois recebimentos ${ }^{18}$. A partir daí, a doutrina passou a estabelecer posicionamentos distintos a respeito do momento de recebimento da denúncia, com o consequente exercício do juízo de admissibilidade.

De acordo com o primeiro posicionamento, e como tal posto na exposição de motivos do Projeto de Lei n. 4.207/2001, o recebimento ocorreria em dois momentos (art. 396 e art. 399). No primeiro momento, o juízo, não rejeitando liminarmente, deve receber a denúncia, interrompendo o prazo prescricional previsto no art. 117, I do CP, para em seguida determinar a citação do acusado para responder por escrito à acusação. No segundo momento, após a resposta defensiva, o juízo realizaria novo recebimento da acusação, adotando um modelo de juízos progressivos ${ }^{19}$. Esta tese é sustentada na doutrina de Grinover, Gomes Filho e Scarance Fernandes ${ }^{20}$, bem como por Eugenio Pacelli21 ${ }^{21}$ que ainda acrescenta não haver exigência constitucional para o exercício da ampla defesa antes da ação penal.

imagem.camara.gov.br/Imagem/d/pdf/DCD30MAR2001VOLI.pdf\#page $=634>$. Acesso em: Acesso em 05 abr. 2020

18 BADARÓ, Gustavo Henrique. Rejeição da denúncia ou queixa e absolvição sumária na reforma do código de processo penal: atuação integrada de tais mecanismos na dinâmica procedimental. Revista Brasileira de Ciências Criminais, São Paulo, v. 17, n. 76, jan./fev. 2009, p. 132.

19 BADARÓ, Gustavo Henrique. Rejeição da denúncia ou queixa e absolvição sumária na reforma do código de processo penal: atuação integrada de tais mecanismos na dinâmica procedimental. Revista Brasileira de Ciências Criminais, São Paulo, v. 17, n. 76, jan/fev 2009, p. 132.

20 GRINOVER, Ada Pellegrini. GOMES FILHO, Antonio Magalhães. FERNADES, Antônio Scarance. As Nulidades no processo penal. 11 ed. São Paulo: Revista dos Tribunais, 2009, p. 87.

21 PACELLI, Eugenio. Curso de processo penal. 18 ed. São Paulo: Atlas, 2014, p. 684 
Outra corrente entende que só há um recebimento, e este ocorreria nos termos do art. 396 do CPP. Nucci ${ }^{22}$, Silva Junior ${ }^{23}$, Rosa ${ }^{24}$, Lopes Jr. ${ }^{25}$ e Giacomolli ${ }^{26}$ defendem que, em uma leitura sistêmica do CPP, todos os atos de decisão (art. 363, 366 e 397 do CPP) ocorrem antes do art. 399, logo, não há que se falar em recebimento neste momento, pois já havia sido recebida na fase do 396 do CPP, o que não impede que o juiz analise se há a possibilidade de absolvição sumária, nos termos do art. 397. Complementa $\mathrm{Choukr}^{27}$ que se o recebimento ocorresse apenas no art. 399, "seria o ápice de concessão ao modelo abstrato do direito de ação".

O terceiro e último posicionamento é endossado por Geraldo Prado $^{28}$, Jacinto Coutinho ${ }^{29}$, Lenio Streck ${ }^{30}$ e Gustavo Badaró ${ }^{31}$, que sustentam que o momento de recebimento da denúncia deveria ser o da fase

${ }^{22}$ NUCCI, Guilherme de Souza. Código de Processo Penal comentado. 12 ed. Rio de Janeiro: Editora Forense, 2016, p. 780.

${ }^{23}$ SILVA JUNIOR, Walter Nunes da. Reforma tópica do processo penal: inovações aos procedimentos ordinário e sumário, com o novo regime das provas, principais modificações do júri e as medidas cautelares pessoais (prisão e medidas diversas da prisão). 2 ed. Rio de Janeiro: Renovar, 2012, p. 106. ROSA, Alexandre Morais da. Guia do processo penal conforme a teoria dos jogos. 5 ed. Florianópolis: Emais, 2019, p. 395.

LOPES JR., Aury. Direito Processual Penal. 16 ed. São Paulo: Saraiva, 2019, p. 728.

GIACOMOLLI, José Nereu. Reformas (?) do Processo Penal: considerações críticas. Rio de Janeiro: Lumen Juris, 2008, p. 74

CHOUKR, Fauzi Hassan. Código de Processo Penal: comentários consolidados \& critica jurisprudencial. 8 ed. Belo Horizonte: D'Plácido, 2018, p. 892.

PRADO, Geraldo. Sobre procedimentos e antinomias. Boletim do IBCCrim, São Paulo, n. 190, set. 2008. p.4-5

COUTINHO, Jacinto Nelson de Miranda. Reformas parciais do processo penal: breves apontamentos críticos. Empório do Direito. 2015. Disponível em: $<$ https://emporiododireito.com.br/leitura/reformas-parciais-do-processo-penal-breves-apontamentos-criticos>. Acesso em 20 abr. 2020.

STRECK, Lenio. O impasse na interpretação do artigo 396 do CPP. Disponível em: <https://www.conjur.com.br/2008-set-18/impasse_interpretacao_artigo_396_cpp>. Acesso em 03 abr. 2020.

BADARÓ, Gustavo Henrique. Rejeição da denúncia ou queixa e absolvição sumária na reforma do código de processo penal: atuação integrada de tais mecanismos na dinâmica procedimental. Revista Brasileira de Ciências Criminais, São Paulo, v. 17, n. 76, jan/fev. 2009, p.133. 
do art. 399 do CPP, isto é, após a apresentação da resposta à acusação. E para isto ocorrer deveria haver uma interpretação corretiva, ab-rogante, a qual excluiria a mesóclise "recebê-la-á". Na mesma esteira, Paulo Rangel ${ }^{32}$ aponta que a expressão "recebê-la-á” não significa a realização do juízo de admissibilidade, mas sim um ato físico de ter em mãos a peça acusatória.

A hipótese de recebimento nos termos do art. 396 não possui "sotaque constitucional" ${ }^{33}$, pois, no texto da CF há regra expressa de que sejam assegurados aos acusados em geral o contraditório e a ampla defesa ( $\mathrm{LV}$, art. $5^{\circ}$ da CF). O juízo fundamentado de admissibilidade só deve ocorrer na fase do art. 399 do CPP, após o oferecimento da resposta à acusação, com sua análise nos termos do art. 397. Este artigo é o referencial que determina a regra de vinculação de fundamentação do juízo de admissibilidade do caso penal. Além disso, a possibilidade de rejeição da denúncia mesmo após a apresentação da resposta à acusação não preclui, sendo que permanece aplicável o art. 395 do CPP, por se tratar de questão de ordem pública.

Mesmo assim, parte da doutrina sustenta a desnecessidade de fundamentação, uma vez que já existiria prova pré-constituída e, consequentemente, haveria justa causa para a ação penal ${ }^{34}$. Silva Jr. ${ }^{35}$ aponta que a liturgia do CPP determina que a fundamentação quanto ao recebimento da acusação será realizada no momento em que a defesa postular, em sede resposta à acusação (art. 396-A), sobre a ausência de condições da ação processual. Eugênio Pacelli ${ }^{36}$ assegura que a decisão de recebimento da

32 RANGEL, Paulo. Direito processual penal. 27 ed. São Paulo: Atlas, 2019, p. 858

33 COUTINHO, Jacinto Nelson de Miranda. Dogmática crítica e limites linguísticos da lei. Revista do Instituto de Hermenêutica Jurídica, Belo Horizonte, v. 1, n. 3, 2005. p. 43.

34 NUCCI, Guilherme de Souza. Código de Processo Penal comentado. 12 ed. Rio de Janeiro: Forense, 2013, p. 780. Entretanto, o autor afirma ter o legislador perdido a chance de instituir o recebimento motivado.

35 SILVA JUNIOR, Walter Nunes da. Reforma tópica do processo penal: inovações aos procedimentos ordinário e sumário, com o novo regime das provas, principais modificações do júri e as medidas cautelares pessoais (prisão e medidas diversas da prisão). 2 ed. Rio de Janeiro: Renovar, 2012, p. 176

36 PACELLI, Eugenio. Curso de processo penal. 21 ed. São Paulo: Atlas, 2017, p. 700 . 
denúncia deve ser realizada nos termos da decisão de pronúncia, guardada as devidas convergências.

De outra sorte, Lopes Jr. e Rosa ${ }^{37}$, Rangel ${ }^{38}$, Gomes Filho ${ }^{39}$ e Badaró $^{40}$ entendem que o recebimento deve ser fundamentado, conforme preceitua o texto constitucional, sob pena de imposição da sanção de nulidade. Não se trata de mero despacho, vez que a decisão de recebimento da acusação (art. 399, CPP) causa verdadeira mudança de status processual para o acusado, que deve se ver apto a ter argumentos suficientes para contrapor o conteúdo do recebimento. A fundamentação da decisão, que deve demonstrar a justificativa motivada por parte do magistrado, não precisa ser complexa e minuciosa, mas deve ser exauriente e explícita quanto aos pontos argumentados na peça defensiva.

Em outras palavras, o que se espera do juiz natural é que analise cuidadosamente os elementos informativos trazidos pela acusação na peça inicial, bem como os argumentos e documentos acostados pela defesa, mormente os que digam respeito a uma abreviação do curso da ação penal por meio da absolvição sumária (art. 397, CPP). A partir deste cabedal probatório, o juiz deverá se pronunciar sobre a possibilidade de continuidade da persecução penal, impondo-lhe a justificação de sua decisão, de modo a possibilitar o exercício do contraditório, ainda que em grau impugnativo, pela parte que entenda ter sido prejudicada pela decisão.

Portanto, o juízo de admissibilidade consiste na análise, pelo juiz, da peça acusatória, nos termos do art. 41 do CPP, e dos argumentos apresentados na resposta à acusação (art. 396-A do CPP), sobre a existência de condições mínimas da ação processual penal (art. 395 CPP), como também sobre as situações de absolvição sumária (art. 397 CPP),

37 LOPES JR., Aury; ROSA, Alexandre Morais da. Quando o acusado é VIP, o recebimento da denúncia é motivado. <Disponível em: https://www.conjur. com.br/2014-nov-14/limite-penal-quando-acusado-vip-recebimento-denuncia-motivado>. Acesso em: 05 abr. 2020. RANGEL, Paulo. Direito processual penal. 27 ed. São Paulo: Atlas, 2019, p. 577 GOMES FILHO, Antônio Magalhães. A motivação das decisões penais. 2 ed. São Paulo: Editora Revista dos Tribunais, 2013, p. 172 2015, p. 603 
nas quais, fundamentadamente (IX, art. 93 da CF c/c art. 315 do CPP), o juiz aponte a existência da pretensão acusatória.

Neste momento é que existe o juízo de admissibilidade da denúncia, o que motiva uma análise sobre seus aspectos quantitativo e qualitativo, a partir da jurisprudência do STJ. Muito embora não tenha sido objeto da pesquisa, seja porque lhe é posterior, seja porque houve suspensão de seus efeitos pelo STF, o art. $3^{\circ}$.-C, acrescentado ao texto do CPP pela Lei n. 13.964/2019, diz textualmente que o momento de recebimento de denúncia ou queixa é o do art. 399, fazendo cessar a competência do juiz de garantias.

\section{Percurso metodológico: do quantitativo ao qualitativo}

A fim de estabelecer parâmetros para identificar o discurso em torno do juízo de admissibilidade da denúncia, utilizou-se a pesquisa de julgados em matéria criminal no sítio eletrônico do STJ. Lançando mão dos critérios disponibilizados na aba de pesquisa jurisprudencial do site, foram pesquisadas decisões proferidas - e não necessariamente publicadas - entre os períodos de 20/08/2008 a 05/08/2019.

A escolha temporal se deu em razão da vigência da Lei n. $11.719 / 2008$ em 20 de agosto daquele ano, com término da pesquisa em agosto de 2019, por se tratar de trabalho originariamente construído para ser apresentado como requisito parcial à aprovação de disciplina cursada no Programa de Pós-Graduação em Direito Constitucional na Universidade de Fortaleza.

Restringiu-se a busca às ações de Habeas Corpus (HC) e Recurso Ordinário em Habeas Corpus (RHC) julgados pela $5^{\mathrm{a}}$ e $6^{\mathrm{a}}$ Turmas e pela

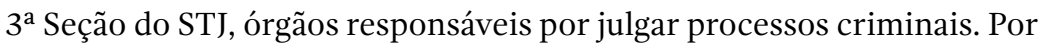
fim, como indexação colocou-se o termo "habeas corpus", evitando as classes processuais que não fossem HC ou RHC. Partiu-se do pressuposto que a contestação a respeito da ausência de fundamentação do juízo de admissibilidade da acusação é mais trabalhada do ponto de vista processual nestes dois institutos, em que o trancamento da ação penal é perseguido, possibilitando resultados mais adequados para a análise quali-quantitativa.

Utilizou-se o termo juízo de admissibilidade da acusação, substituindo as preposições "de" e "da" pelos conectivos adj2 e prox10, por exemplo, 
juízo adj2 admissibilidade adj2 acusação e juízo prox10 admissibilidade prox10 acusação. A exclusão das preposições, conforme orientação no próprio site do STJ, tem por objetivo filtrar de forma mais eficiente o resultado da pesquisa, refinando-a com base em critérios científicos e eliminando ao máximo a imprecisão. E o substantivo acusação foi substituído por denúncia, seguindo a mesma sistemática, com alternância dos conectivos.

Utilizando os termos juízo adj2 admissibilidade adj2 denúncia, foram encontrados 7 acórdãos. Por conseguinte, ainda com o termo denúncia, mas com o conectivo prox 10, foram encontrados 16 acórdãos. Usando o termo de pesquisa juízo adj2 admissibilidade adj2 acusação, foram encontrados 183 acórdãos; modificando o conectivo para prox10, foram encontrados 207 acórdãos. A coleta e sistematização dos dados prescindiu de aporte tecnológico além do já utilizado para obtenção dos resultados que se apresentam mais adiante. De qualquer modo, uma organização mínima por assunto foi realizada, com anotação manual dos dados obtidos. Posteriormente foram feitas duas revisões dos dados, não havendo discrepância entre eles. ${ }^{41}$

O primeiro filtro realizado foi em relação à classe processual (HC ou RHC), no que foram extraídos 204 acórdãos sem repetição, sendo realizada uma nova triagem para excluir processos oriundos do Tribunal do Júri, já que, nestes casos, o juízo de admissibilidade se dá pela prolação da decisão de pronúncia ou da sentença de impronúncia. Restaram 107 acórdãos, cuja análise abrangeu leitura completa da ementa e votos; contudo, alguns julgados apresentam melhor compreensão na ementa do que no próprio teor do voto.

Finalizada a coleta dos dados, foram elaboradas algumas diretrizes para a investigação tanto qualitativa, quanto quantitativa: i) tipo de processo; ii) ocorrência de divergência; iii) trancamento da ação penal

41 Embora utilizando-se de metodologia ligeiramente distinta, com outras expressões-chave de pesquisa e com quantitativo superior (145) ao analisado neste trabalho (107), o artigo escrito em coautoria por Antônio Santoro, Mauro Borges Neto e Nilo Pompílio da Hora chega às mesmas conclusões deste trabalho no tocante à insubmissão destas decisões à necessidade de fundamentação, em descompasso com o texto constitucional. (SANTORO, Antônio Eduardo Ramires; BORGES NETO, Mauro Leibir Machado; DA HORA, Nilo César Martins Pompílio. A (in)exigibilidade da decisão que ratifica o recebimento da denúncia: uma análise da jurisprudência do Superior Tribunal de Justiça. Revista Direitos Fundamentais \& Justiça, Belo Horizonte, a. 13, n. 40, p. 85-113, jan./jun. 2019). 
originária; iv) referência ao art. 93, IX da CF no corpo do acórdão; v) órgão do STJ responsável pelo julgamento. Com relação à existência ou não de divergência, verificou-se que tal dado é relevante para demonstrar que ela não ocorreu, ou seja, em $100 \%$ dos resultados obtidos os votos foram por unanimidade.

No que se refere ao tipo de processo, observou-se que a maioria dos acórdãos analisados são de RHC, representado 65,4\% dos julgados analisados. Os HC representaram 34,6\%, o que sugere a efetivação da jurisprudência defensiva do STJ em relação a não aceitar HC substitutivo de RHC.

\section{Qual é a espécie processual?}

107 respostas

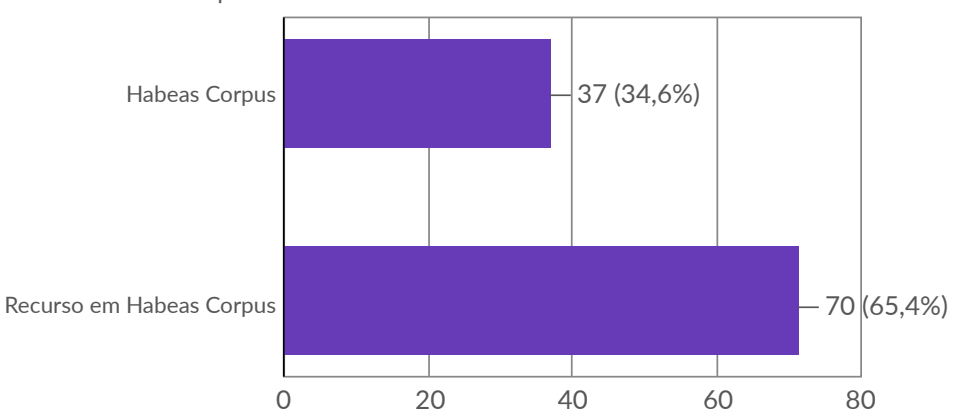

Buscou-se também saber se dentre os julgados houve trancamento da ação penal. Em 92,5 \% dos acórdãos não ocorreu o referido trancamento do processo penal, por fundamentos que serão analisados no tópico terceiro deste estudo.

Houve trancamento da ação penal originária?

107 respostas

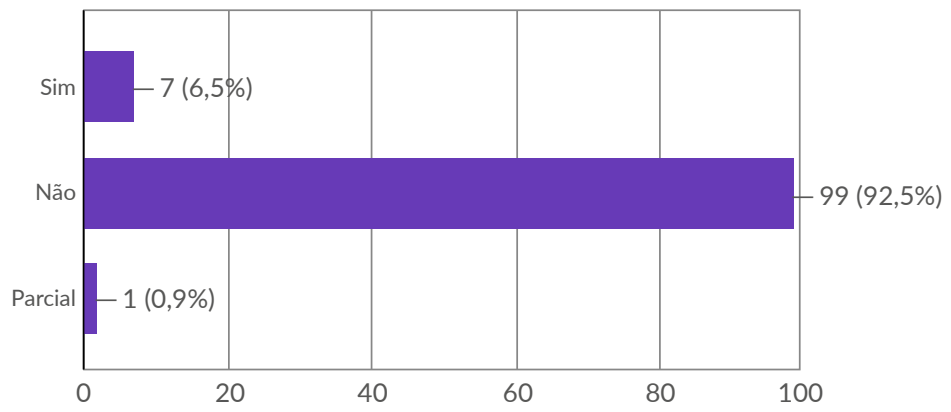

Rev. Bras. de Direito Processual Penal, Porto Alegre, v. 7, n. 1, p. 511-534, jan.-abr. 2021. 
Depois, investigou-se se nos julgados houve citação do comando normativo constitucional do art. 93, IX da CF. Em 82,2\% dos acordãos analisados não houve qualquer menção à obrigataoriedade da fundamentaçao das decisões.

Referência ao Art. 93, IX da CF?

107 respostas

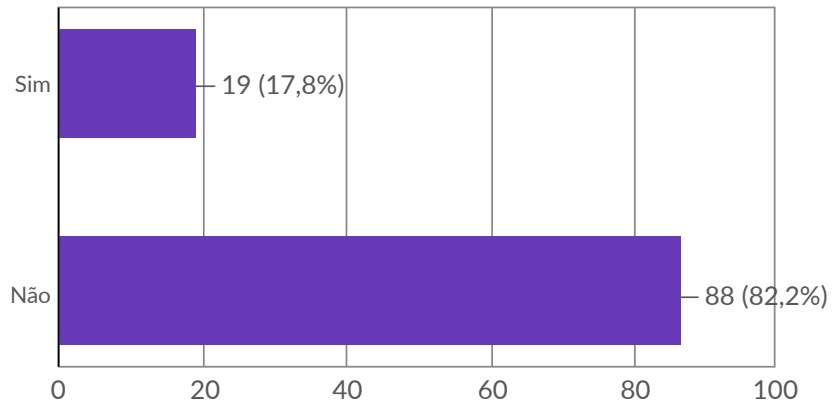

Por fim, buscou-se identificar qual orgão julgador dentro do STJ possuía maior incidência dos julgados referentes ao art. 396 do CPP. A maioria dos julgados é oriunda da $5^{\text {a }}$ Turma, representando um percentual de $89,7 \%$. Na $6^{\mathrm{a}}$ Turma há apenas $10,3 \%$ dos julgados e em relaçao à $3^{\mathrm{a}}$ Seção não houve nenhum julgado.

Qual foi a turma ou secção responsável pelo julgamento?

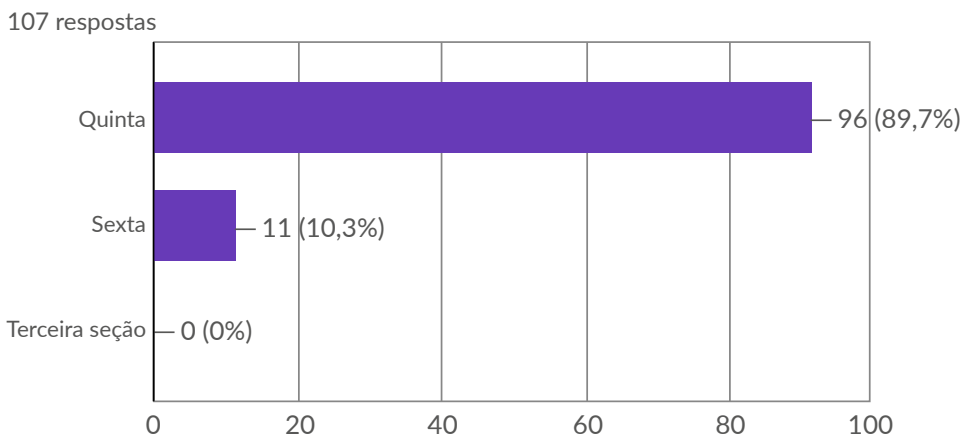

No próximo tópico será feito o estudo qualitativo dos acórdãos, de modo a saber o "estado da arte" do discurso em relação ao juízo de admissibilidade da acusação no âmbito do STJ. 


\section{O DISCURSO DO STJ EM TORNO DO JUÍZO DE ADMISSIBILIDADE DA DENÚNCIA}

O debate toma forma ao serem analisados os 107 acórdãos, dos quais destacam-se quatro expressões que foram selecionadas por serem repetitivas nos julgados, a saber: i) in dubio pro societate; ii) a decisão de recebimento possui natureza interlocutória cautelar; iii) o juízo deve ater-se à admissibilidade da imputação; e, por último, iv) o argumento da exigência da fundamentação em concreto:

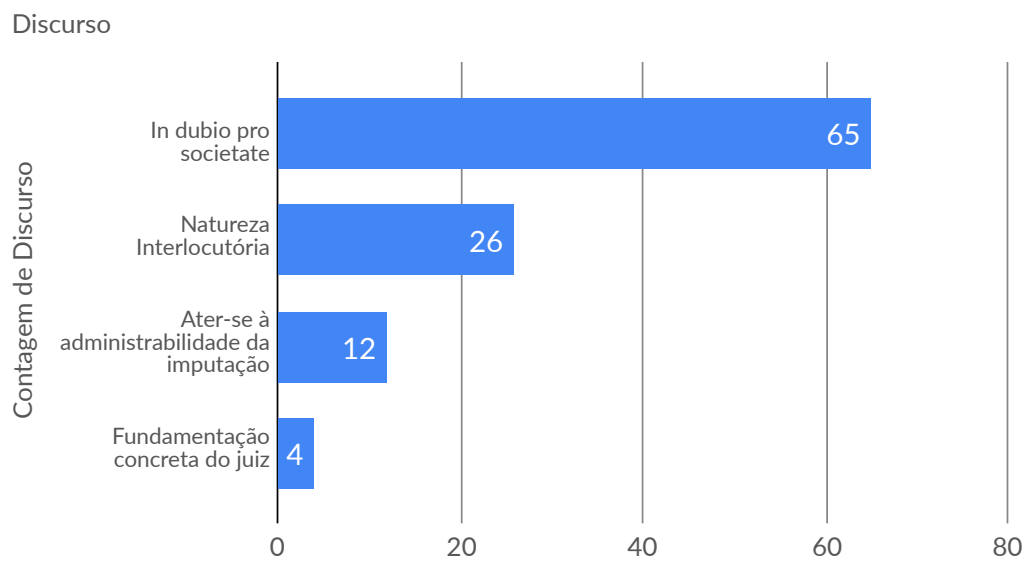

O discurso mais utilizado nos julgados pesquisados ${ }^{42}$ entendeu que na fase do juízo de admissibilidade vigora o in dubio pro societate, isto é, na dúvida quanto à existência da pretensão punitiva, deve ser a decisão em favor da sociedade, com o prosseguimento da acusação, uma vez que não deve se falar em encerrar o "jus accusationis do Estado", com ressalva nas hipóteses de manifesta carência de justa causa.

O discurso em torno do in dubio pro societate apresenta falha em sua estrutura jurídica. Em primeiro lugar, a única presunção que se tem no processo é da inocência (art. $5^{\circ}$, LVII da CF, art. $8^{\circ}, 2$, da CADH). Não existe densidade normativa para que se eleve o referido brocado ao

42 Destaca-se o julgado STJ. RHC n. 88.892/MA. $5^{\text {a }}$ Turma. Rel. Ministro Ribeiro Dantas. 20 fev. 2018. 
patamar de princípio constitucional, tendo em vista ser todo princípio portador de uma regra que o sustenta ${ }^{43}$. $\mathrm{O}$ argumento in dubio pro societate é tão paradoxal que há decisões em que ele é utilizado tanto para conceder a ordem ${ }^{44}$ como também para negá-la. Aponta-se como uma "gambiarra retórica" ${ }^{45}$ utilizada por comodismo dos julgadores em escapar da obrigação de fundamentar as decisões judiciais e, mais do que isso, manter consolidada a mentalidade inquisitória no Brasil.

Na estrutura dialética que envolve o processo penal, o que se põe em dúvida é, tão somente, a acusação ${ }^{46}$ e não a presunção da inocência do acusado. Ao pairar dúvidas quanto à existência de pretensão acusatória, deve-se absolver o acusado por falta de provas, ou, em um estágio inicial, recusar-se o recebimento da denúncia. A ação processual penal é guiada pela busca da certeza (verdade), e a presunção da inocência tem como função a produção da incerteza ${ }^{47}$, assim, na dúvida in dubio pro reo.

A aplicação do argumento do in dubio pro societate passa a ser considerado um contrassenso ao texto constitucional. Por isso, sua aplicação só se justifica por uma negação a ele, em decorrência da existência de ranços inquisitórios nos atores da persecução criminal ${ }^{48}$ e também do magistrado

${ }^{43}$ FERRAJOLI, Luigi. Constitucionalismo principialista e constitucionalismo garantista. Trad. André Karam Trindade. In. STRECK, Lenio Luis. KARAN, André Trindade (Org). Garantismo, hermenêutica e (neo) constitucionalismo: um debate com Luigi Ferrajoli. Primeira parte. Porto Alegre: Livraria do Advogado, 2012. p. 39.

${ }_{44}$ No HC n. 426.706/MG, julgado pela $5^{\text {a }}$ Turma do STJ, utiliza o discurso em torno do in dubio pro societate para concedeu a ordem de ofício para trancar parcialmente ação processual penal quanto a um dos crimes imputados

45 ROSA, Alexandre Morais da. KHALED JR., Salah H. In dubio pro hell: profanando o sistema penal. 3 ed. Florianopolis: Emais, 2018, p. 137.

46 PACELLI, Eugênio. O processo penal como dialética da incerteza. Revista de Informação legislativa. Brasília, n. 183, jul.-set., 2009, p.74.

47 PRADO, Geraldo. Prova penal e sistema de controle epistêmicos... Obra citada. p. 17.

48 SANTIAGO, Nestor E. A.; BRAGA, I. F.; MAMEDE, J. M. B.; FRANCO, B. S. D.; XIMENES, L. M. P. Dúvida e processo penal: procedimento do tribunal do júri, decisão de pronúncia e o in dubio pro societate. Católica Law Review, Lisboa, v. III, n. 3, p. 43-61, 2019. p. 56 
Em segundo momento, foram diagnosticados 26 julgados ${ }^{49} \mathrm{em}$ que o discurso decisório aponta para a natureza interlocutória da decisão do juízo de admissibilidade e, com isso, passa a não exigir sua fundamentação. Tal entendimento é incompatível com o texto da Constituição Federal, uma vez que em seu bojo assegura a todo acusado o direito ao devido processo legal (art. $5^{\circ}$, LIV) e a efetivação desta garantia passa por uma fundamentação da decisão judicial (art. 93, IX).

O simples fato de se imputar criminalmente a alguém um fato típico penal já produz efeitos estigmatizantes, e a apresentação da acusação, que nem sempre vem a reboque de uma investigação preliminar, traz ao imputado as consequências das penas processuais ${ }^{50}$. Assim, torna-se necessário um maior rigor no filtro da pretensão acusatória, sendo necessário proteger o acusado das penas processuais provocadas pela acusação ${ }^{51}$.

Destarte, o juízo de admissibilidade da denúncia é de natureza decisória, o que pode parecer redundante, mas numa leitura da CF toda decisão deve ser fundamentada, sob pena de nulidade - e da Lei n. 11.719/08, que inclui uma fase intermediária ao qual o juízo, ao verificar a existência da pretensão acusatória, poderá transformar o cidadão em acusado, devendo este suportar toda a carga do etiquetamento; logo, não se pode falar em ausência de conteúdo decisório. Tal necessidade de fundamentação do juízo de admissibilidade representa um avanço no não só para o direito de defesa, mas para o próprio contraditório.

O terceiro argumento pinçado, repetido em 12 acórdãos, entende que o juízo deve se atentar aos pressupostos processuais, das condições da ação penal, bem como da materialidade e autoria delitivas, isto de

49 Destaca o seguinte trecho "Com efeito, nos termos da jurisprudência desta Corte Superior, é perfeitamente admissível e válido o recebimento da denún-

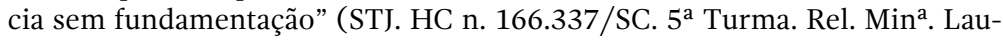
rita Vaz, 12 de junho 2012. p. 3)

50 As penas processuais são definidas por Aury Lopes Jr. como a elevada carga que o sujeito passivo deve suportar durante o processo, dentre estas destaca os "estigmas social e jurídica, angústia e sofrimento psíquico, constrangimento inerente à submissão ao exercício do poder estatal etc”. (LOPES JR. Aury. Direito processual penal. 16. ed. São Paulo: Saraiva, 2019, p. 730)

51 ZILLI, Marcos. O povo contra... As condições da ação penal condenatória. Velhos problemas. Novas ideias. Cadernos Jurídicos, São Paulo, n. 44, p.147-162, jul.set. 2016. 
maneira sucinta, para que se atenda no mínimo possível à Constituição ${ }^{52}$ no que tange à necessidade de fundamentação.

Ao endossar tal entendimento, transforma-se o juízo de admissibilidade em um instituto de natureza meramente procedimental, isto é, apenas um despacho judicial, de caráter meramente impulsionador do processo. Aponta que o recebimento da denúncia não exige uma cognição complexa, mas tão somente se deve constatar a "regularidade da peça acusatória inicial”.

Entretanto, a decisão proferida no juízo de admissibilidade da acusação não possui caráter definitivo, mesmo que de absolvição ou rejeição, o qual ainda estará pendente de impugnação naquele e nesta poderá novamente ser apresentada. O juízo de admissibilidade trata de um juízo provisório da culpabilidade ${ }^{53}$, isto é, de uma probabilidade que poderá ou não ser confirmada em sentença. Assim, pretende nesta fase intermediária verificar se há viabilidade da propositura da ação processual penal, em que deve ser feita à luz do princípio da estrita jurisdicionariedade, verificabilidade e da comprovação empírica da acusação ${ }^{54}$.

Por fim, em apenas quatro acórdãos ${ }^{55}$ foi exigido que a decisão deveria apresentar de maneira pormenorizada se estariam presentes os pressupostos para a deflagração da persecução penal. Tal entendimento cumpre o comando normativo constitucional do dever de fundamentação

52 STJ. $H C N^{o} 248.795 / P B$. $6^{a}$ Turma. Rel. Ministra Maria Thereza de Assis Moura. 19 ago. 2014.

53 GIACOMOLLI, Nereu José. O devido processo Penal: abordagem conforme a Constituição Federal e o Pacto de São José da Costa Rica. 2 ed. São Paulo: Editora Atlas, 2015, p. 235.

54 FERRAJOLI, Luigi. Direito e razão. 4 ed. São Paulo: Revista dos Tribunais, 2014, p. 558.

55 Destaca o seguinte trecho "É certo que não se pode exigir, nesta fase do procedimento, uma cognição plena da matéria elencada pela defesa, visto que uma decisão de mérito só será possível após a regular instrução do processo. Contudo, em contraponto, não se pode confundir fundamentação concisa com ausência de fundamentação. A análise da resposta à acusação merece, sim, uma manifestação concreta do Juiz." (STJ. RHC n. 59.930/SP. 6a turma. Rel. Min Sebastião Reis Júnior. 04 jun. 2016. p. 7.). Ver, ainda: STJ. RHC n. 60.705/ PE. $5^{\mathrm{a}}$ turma. Rel. Min Ribeiro Dantas. 05 out. 2017; STJ. RHC n. 74.176/RJ. $5^{\mathrm{a}}$ turma. Rel. Min Reynaldo Soares da Fonseca. 22 nov. 2016.; STJ. HC n. 253.920/MG. $6^{\text {a }}$ turma, Rel. Min Maria Thereza Assis Moura. 05 ago. 2014. 
das decisões, isto é, do controle empírico da acusação. E tal compreensão é imposta pelo art. 93, IX da CF, com detalhamento maior tanto no $\S 2^{\circ}$ do art. 315 do CPP.

Portanto, a decisão de recebimento da denúncia deve ser fundamentada, não permitindo que o julgador aponte apenas o ato normativo sem explicar relação com o fato ou que não enfrente todas as questões suscitadas pela defesa.

\section{Considerações Finais}

A pesquisa demonstrou que dos 107 acórdãos analisados, 65 destes apontaram que no juízo de admissibilidade da denúncia vigora o argumento do in dubio pro societate. Já em 26 julgados, a decisão da fase intermediária possui natureza interlocutória. Outros 12 determinaram que o juiz deve se ater às condições da ação processual para que se apresente fundamentação sucinta sobre o recebimento ou rejeição da denúncia. Por fim, em 4 julgados entendeu-se que o juiz deve apresentar fundamentação concreta.

Desta forma, o STJ, ao majoritariamente entender que no juízo de admissibilidade da denúncia vigora in dubio pro societate e consequentemente reforçar a desnecessidade de uma fundamentação, mina uma das bases do constitucionalismo garantista. A Constituição Federal, ao determinar em seu art. 93, IX, que toda decisão judicial deve ser fundamentada, procura assegurar uma garantia ao acusado em entender que o juiz está exercendo sua função de maneira imparcial e racional nos termos do sistema legal vigente.

O processo penal tem como escopo a proteção das garantias fundamentais e a proteção do jurisdicionado, regulando o poder punitivo estatal. Assim, o juízo de admissibilidade da acusação estabelecido pela Lei n. 11.719/08 é estruturado para prover um controle maior sobre a denúncia, a fim de evitar a proliferação de acusações temerárias.

Nesta medida, em uma leitura do texto constitucional a decisão sobre o juízo de admissibilidade possui caráter decisório, uma vez que o CPP deixa claro a existência de uma fase intermediária entre a investigação preliminar e a instrução probatória e esta mudança do status (de 
investigado para acusado) necessita de uma demonstração racional por parte do estado-juiz ${ }^{56}$. Posto isto, o juiz, ancorado no art. 93, IX da CF, e agora também no $\S 2^{\circ}$. do art. 315 do CPP, deve fundamentar a decisão.

Conclui-se que o Superior Tribunal de Justiça oferece uma resposta inadequada ao texto constitucional ao entender que o juízo de admissibilidade seria apenas uma fase discricionária, a qual o juiz poderia prosseguir com a persecução penal, mesmo no estado de dúvida.

\section{REFERÊNCIAS}

BADARÓ, Gustavo Henrique. Processo Penal. 3 ed. São Paulo: Revista dos Tribunais, 2015.

BADARÓ, Gustavo Henrique. Rejeição da denúncia ou queixa e absolvição sumária na reforma do código de processo penal: atuação integrada de tais mecanismos na dinâmica procedimental. Revista Brasileira de Ciências Criminais, São Paulo, v. 17, n. 76, p. 123-180, jan.-fev. 2009

BASTOS, Marcio Thomaz. Reformar o processo penal. Folha de São Paulo. Disponível em: < https://www1.folha.uol.com.br/fsp/brasil/fc2411200316.htm>. Acesso em 05 abr. 2020.

CHOUKR, Fauzi Hassan. Código de Processo Penal: comentários consolidados \& critica jurisprudencial. 8 ed. Belo Horizonte: D’Plácido, 2018.

COUTINHO, Jacinto Nelson de Miranda. Dogmática crítica e limites lingüísticos da lei. Revista do Instituto de Hermenêutica Jurídica, Belo Horizonte, v. 1, p. 37-44, 2005. COUTINHO, Jacinto Nelson de Miranda. Reformas parciais do processo penal: breves apontamentos críticos. Empório do Direito. 2015. Disponível em: <https:// emporiododireito.com.br/leitura/reformas-parciais-do-processo-penal-breves-apontamentos-criticos>. Acesso em 20 abr. 2020.

FERRAJOLI, Luigi. Direito e razão. 4 ed. São Paulo: Revista dos Tribunais, 2014.

56 Muito embora não tenham se valido de pesquisa quantitativa, mas meramente documental, as conclusões de Marcelo Souza e Jussara Jacintho são neste mesmo sentido. (SOUZA, Marcelo Serrano; JACINTHO, Jussara Maria Moreno. O recebimento implícito ou tácito da denúncia no processo penal como hipótese de violação aos princípios do devido processo legal e da motivação das decisões. Revista Direito Penal, Processo Penal e Constituição, Brasília, v. 2, n. 1, p. 556-571, jan./jun. 2016) 
FERRAJOLI, Luigi. Constitucionalismo principialista e constitucionalismo garantista. Trad. André Karam Trindade. In. STRECK, Lênio Luis. KARAN, André Trindade (Org). Garantismo, hermenêutica e (neo) constitucionalismo: um debate com Luigi Ferrajoli. Primeira parte. Porto Alegre: Livraria do Advogado, 2012. p. 8-32. GIACOMOLLI, José Nereu. Reformas (?) do Processo Penal: considerações críticas. Rio de Janeiro: Lumen Juris, 2008.

GIACOMOLLI, Nereu José. O devido processo penal: abordagem conforme a Constituição Federal e o Pacto de São José da Costa Rica. 2 ed. São Paulo: Editora Atlas. 2015.

GOMES FILHO, Antônio Magalhães. A motivação das decisões penais. 2 ed. São Paulo: Editora Revista dos Tribunais, 2013.

GRINOVER, Ada Pellegrini. A reforma do Código de Processo Penal. Revista Brasileira de Ciências Criminais, São Paulo, v. 31, p. 65-74, jul-set. 2000.

GRINOVER, Ada Pellegrini. GOMES FILHO, Antônio Magalhães. FERNANDES, Antonio Scarance. As nulidades no processo penal. 11 ed. São Paulo: Revista dos Tribunais, 2009.

LOPES JR., Aury. Direito Processual Penal. 16 ed. São Paulo: Saraiva, 2019.

LOPES JR., Aury.; ROSA, Alexandre Morais da. Quando o acusado é VIP, o recebimento da denúncia é motivado. Consultor jurídico. Disponível em: https://www. conjur.com.br/2014-nov-14/limite-penal-quando-acusado-vip-recebimento-denuncia-motivado. Acesso em: 05 abril. 2020.

NUCCI, Guilherme de Souza. Código de Processo Penal comentado. 12 ed. Rio de Janeiro: Editora Forense, 2013.

PACELLI, Eugenio. Curso de processo penal. 18 ed. São Paulo.: Atlas, 2014.

PACELLI, Eugenio. O processo penal como dialética da incerteza. Revista de Informação Legislativa, Brasília, n. 183, p. 67-75, jul.-set. 2009.

PRADO, Geraldo. Crônica da reforma do Código de Processo Penal Brasileiro que se inscreve na disputa policia pelo sentido e fundação da justiça criminal. In: COUTINHO, Jacinto Miranda. CARVALHO, L. G. Grandinetti Castanho de. (Org.). O novo Processo Penal à Luz da Constituição. Rio de Janeiro: Lumen Juris, 2011.

PRADO, Geraldo. Prova penal e sistema de controles epistêmicos: a quebra da cadeia de custódia das provas obtidas por métodos ocultos. São Paulo: Marcial Pons, 2014. PRADO, Geraldo. Sobre procedimentos e antinomias. Boletim do IBCCrim, São Paulo, n. 190, p. 4-5, set. 2008.

RANGEL, Paulo. Direito processual penal. 27 ed. São Paulo: Atlas, 2019. 
ROSA, Alexandre Morais da. Guia do processo penal conforme a teoria dos jogos. 5 ed. Florianópolis: Emais, 2019.

ROSA, Alexandre Morais da. KHALED JR., Salah H. In dubio pro hell: profanando o sistema penal. 3 ed. Florianópolis: Emais, 2018.

SANTIAGO, Nestor Eduardo Araruna. Princípio da duração razoável do processo e direito processual penal: uma leitura estrutural da mini-reforma. In: SALES, Gabrielle Bezerra; JUCÁ, Roberta Laena Costa. (Org.). Constituição em Foco: 20 anos de um novo Brasil. 1 ed. Fortaleza: LCR, 2008.

SANTIAGO, Nestor E. A.; BRAGA, I. F.; MAMEDE, J. M. B.; FRANCO, B. S. D.; XIMENES, L. M. P. Dúvida e processo penal: procedimento do tribunal do júri, decisão de pronúncia e o in dubio pro societate. Católica Law Review, Lisboa, v. III, n. 3, p. 43-61, 2019.

SANTORO, Antônio Eduardo Ramires; BORGES NETO, Mauro Leibir Machado; DA HORA, Nilo César Martins Pompílio. A (in)exigibilidade da decisão que ratifica o recebimento da denúncia: uma análise da jurisprudência do Superior Tribunal de Justiça. Revista Direitos Fundamentais \& Justiça, Belo Horizonte, a. 13, n. 40, p. 85-113, jan./jun. 2019. https://doi.org/10.30899/dfj.v13i40.647

SILVA JUNIOR, Walter Nunes da. Reforma tópica do processo penal: inovações aos procedimentos ordinário e sumário, com o novo regime das provas, principais modificações do júri e as medidas cautelares pessoais (prisão e medidas diversas da prisão). 2 ed. Rio de Janeiro: Renovar, 2012.

SOUZA, Marcelo Serrano; JACINTHO, Jussara Maria Moreno. O recebimento implícito ou tácito da denúncia no processo penal como hipótese de violação aos princípios do devido processo legal e da motivação das decisões. Revista Direito Penal, Processo Penal e Constituição, Brasília, v. 2, n. 1, p. 556-571, jan./jun. 2016. https://doi.org/10.26668/indexlawjournals/2526-0200/2016.v2i1.847

STRECK, Lenio Luiz. Hermenêutica jurídica e $(m)$ crise: uma exploração hermenêutica da construção do Direito. 11 ed. Porto Alegre: Livraria do Advogado, 2014.

STRECK, Lenio. O impasse na interpretação do artigo 396 do CPP. Consultor Jurídico. Disponível em: <https://www.conjur.com.br/2008-set-18/impasse_interpretacao_artigo_396_cpp>. Acesso em 03 abr. 2020.

STRECK, Lenio Luiz. O que é isto - decido conforme minha consciência? Porto Alegre: Livraria do Advogado, 2015.

ZILLI, Marcos. O pomar e as pragas. Boletim do IBCCRIM, n.188, jul. 2008.

ZILLI, Marcos. O povo contra... As condições da ação penal condenatória. Velhos problemas. Novas ideias. Cadernos Jurídicos. São Paulo, n. 44, p.147-162, jul.- set. 2016. 


\section{Informações adicionais e declarações dos autores (integridade científica)}

Declaração de conflito de interesses (conflict of interest declaration): os autores confirmam que não há conflitos de interesse na realização das pesquisas expostas e na redação deste artigo.

Declaração de autoria e especificação das contribuições (declaration of authorship): todas e somente as pessoas que atendem os requisitos de autoria deste artigo estão listadas como autores; todos os coautores se responsabilizam integralmente por este trabalho em sua totalidade.

- João Henrique Andrade: projeto e esboço inicial (conceptualization), desenvolvimento da metodologia (methodology), coleta e análise de dados (data curation), levantamento bibliográfico (investigation), redação (writing - original draft), participação ativa nas discussões dos resultados (validation), aprovação da versão final.

- Nestor Eduardo Araruna Santiago: participação ativa nas discussões dos resultados (validation), revisão crítica com contribuições substanciais (writing - review and editing), aprovação da versão final.

- Uinie Caminha: projeto e esboço inicial (conceptualization), desenvolvimento da metodologia (methodology), participação ativa nas discussões dos resultados (validation), revisão crítica com contribuições substanciais (writing review and editing), aprovação da versão final.

Declaração de ineditismo e originalidade (declaration of originality): os autores asseguram que o texto aqui publicado não foi divulgado anteriormente em outro meio e que futura republicação somente se realizará com a indicação expressa da referência desta publicação original; também atestam que não há plágio de terceiros ou autoplágio. 


\section{Dados do processo editorial}

(http://www.ibraspp.com.br/revista/index.php/RBDPP/about/editorialPolicies)

- Recebido em: 19/05/2020

Equipe editorial envolvida

- Controle preliminar e verificação de plágio: 12/06/2020

- Avaliação 1: 15/06/2020

- Avaliação 2: 16/06/2020

- Avaliação 3: 02/07/2020

- Avaliação 4: 08/07/2020

- Decisão editorial preliminar: 30/08/2020

- Retorno rodada de correções 1: 20/10/2020

- Decisão editorial preliminar 2: 18/11/2020

- Retorno rodada de correções 2: 19/01/2021

- Decisão editorial final: 28/01/2021

\section{COMO CITAR ESTE ARTIGO:}

ANDRADE, João Henrique; SANTIAGO, Nestor Eduardo Araruna; CAMINHA, Uinie. Decisão de admissibilidade da denúncia no Superior Tribunal de Justiça: uma pesquisa quali-quantitativa. Revista Brasileira de Direito Processual Penal, Porto Alegre, vol. 7, n. 1, p. 511-534, jan./abr. 2021. https://doi.org/10.22197/rbdpp.v7i1.389

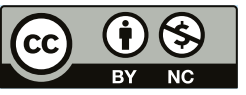

Esta obra está licenciada com uma Licença Creative Commons Atribuição-NãoComercial 4.0 Internacional. 